\title{
Analysis of Demand Potential and Need for Passenger Terminal Facilities at Cikembar Sukabumi Airport
}

\author{
Agung Setiawan ${ }^{1}$, Juang Akbardin², Johar Maknun ${ }^{3}$ \\ ${ }^{1}$ Magister Arsitektur FPTK Universitas Pendidikan Indonesia, Bandung, Indonesia \\ ${ }^{2}$ Teknik Sipil FPTK Universitas Pendidikan Indonesia, Bandung, Indonesia \\ ${ }^{3}$ Teknik Arsitektur FPTK Universitas Pendidikan Indonesia, Bandung, Indonesia \\ corresponding author: agungsetiawan@upi.edu \\ akbardien@upi.edu \\ joharmaknun@upi.edu
}

\begin{abstract}
West Java Province has a very unique and strategic geographic field challenge as a province with the largest population in Indonesia and as a province that is at the forefront of supporting the rapid dynamics of development in the capital city DKI Jakarta. In realizing equitable development, as stated in the West Java Provincial Medium-Term Development Plan (RPJMD) 2018-2023, infrastructure development is regulated in a priority scheme that aims to bring equitable development. One of the planned transportation infrastructure developments in the construction of Cikembar Airport, Sukabumi, is prepared to serve the development area (WP) of the Sukabumi area and its surroundings which is targeted for completion in 2023. In preparing the airport design, a projection analysis based on demand is needed first. which correlates with statistical data. Forecasting analysis (forecasting) the number of passengers at Cikembar Airport aims to obtain potential passenger demand and a description of the needs for terminal facilities through the collection of statistical data to be analyzed using the correlation method and the multiple linear regression method between the number of passengers as the dependent variable. Meanwhile, statistical variables such as population growth, tourist growth, and Gross Regional Domestic Product (GRDP), Sukabumi, and West Java Regencies were determined as independent variables. In formulating the terminal room facilities, it refers to the standards issued by the Directorate General of Civil Aviation through SKEP No.77/VI Year 2005. Considering the moderate upward trend approach, the estimated number of passengers at Cikembar Airport passenger terminal in 2023, namely the year the airport is planned to be realized, is as much as 756,029 passengers with busy time passengers totaling 605 passengers. The operational area needed for the terminal in that year was $8,468 \mathrm{~m}^{2}$. Assuming the concession area provided is $30 \%$, the total terminal area required is $11,643 \mathrm{~m}^{2}$. This area projection still meets the needs based on the estimated terminal area attached to the Cikembar Airport master plan, which is $12,000 \mathrm{~m}^{2}$.
\end{abstract}

Keywords - Demand Potential Analysis, Space Requirements, Cikembar Sukabumi Airport Terminal

\section{Introduction}

The urgency of planning, constructing, and developing airport facilities in Indonesia is inseparable from the geographical characteristics of its territory which stretches out wide and consists of thousands of archipelago segments separated by oceans. This condition presents a big challenge for the government to be able to provide transportation infrastructure that can connect between regions. This connectivity network is very important so that the continuity of development can run evenly throughout the country. So far, many aircraft have been chosen as a mode of 
transportation for passengers and cargo which is very reliable to reach various remote areas that have limited accessibility by land and sea modes. Therefore, the need for airports will increase the number of passengers that must be served. It is recorded that during the last decade, the increase in the number of air transport users in Indonesia has reached 15\% (Sefrus: 2017).

West Java Province has a geographic area of $35,377.76 \mathrm{~m} 2$ consisting of 27 districts/cities. As a province directly adjacent to DKI Jakarta, West Java has strategic advantages as a support area for rapid development in the capital and its surroundings. As outlined in the West Java Provincial Medium-Term Development Plan (RPJMD) 2018-2023, the West Java Provincial Government has set some priority infrastructure development programs to strengthen a connected transportation system. This priority program is known as "Champion Transportation" ranks the priority of the transportation sector in the form of the runway extension and the development of Kertajati West Java International Airport in Majalengka District, Cikembar Airport Development Sukabumi District, Optimization of Nusawiru Airport in Pangandaran District, regional feeder port in Sukabumi District. , Pangandaran District and Cirebon City. The philosophical basis of these development priorities is the achievement of "Balanced Development and Building Urban Mass Transportation" in West Java Province (Permana and Wijaya, 2017).

This vision of equitable development is further outlined through Perda No. 22/2010 concerning the West Java Regional Spatial Plan (RTRW) with the determination of six Development Areas (WP), namely WP I Bodebekpunjur (Bogor, Depok, Bekasi, Puncak, Cianjur) and its surroundings, WP II Purwasuka (Purwakarta-Subang-Karawang), WP III Bandung Basin, WP IV Ciayumajakuning (Cirebon, Indramayu, Majalengka and Kuningan), WP V Priangan timurPangandaran, and WP VI Sukabumi and its surroundings. In the context of developing air transport infrastructure, WP I, which is very close to DKI Jakarta, is served by Soekarno Hatta International Airport in Cengkareng, Tangerang, Banten. Meanwhile, WP III, WP IV and WP V are each served by Husein Sastranegara Airport in Bandung, Kertajati Airport in Majalengka and Nusawiru Airport in Pangandaran. Until now, the two development areas, namely WP II and WP VI, are still not being served by airports and are forced to travel quite a long distance to the nearest airport in other development areas. So far, there has been a plan to build airports in Karawang and Sukabumi to catch up.

\section{Regional Development Policy}

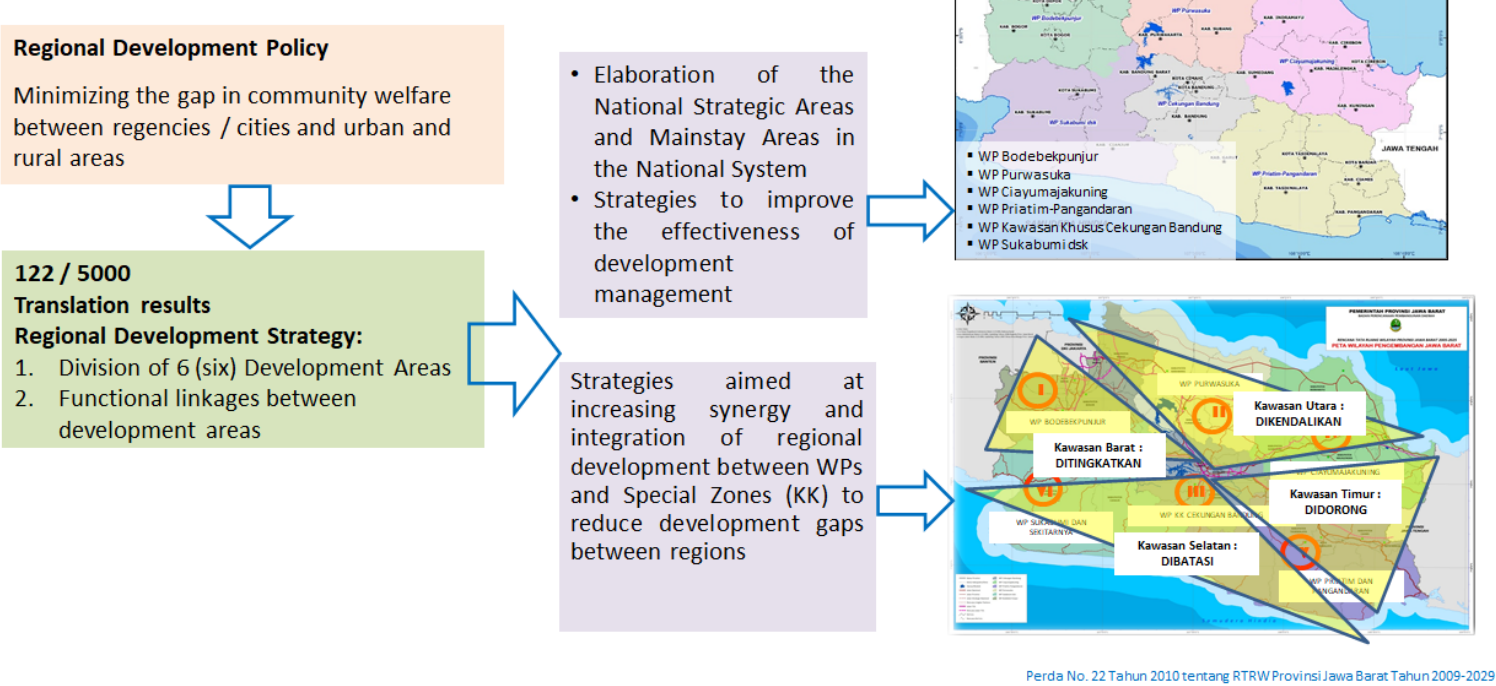

Figure 1: West Java Province Development Area Policy (WP).

Source: Bappeda Provinsi Jawa Barat 
DEVELOPMENT THEMES: ENCOURAGING THE DEVELOPMENT OF THE SUKABUMI-CIANJUR CORPORATE AND PALABUHANRATU PKW, AS WELL AS LIMITING THE DEVELOPMENT IN THE SOUTH OF SUKABUMI AND CIANJUR

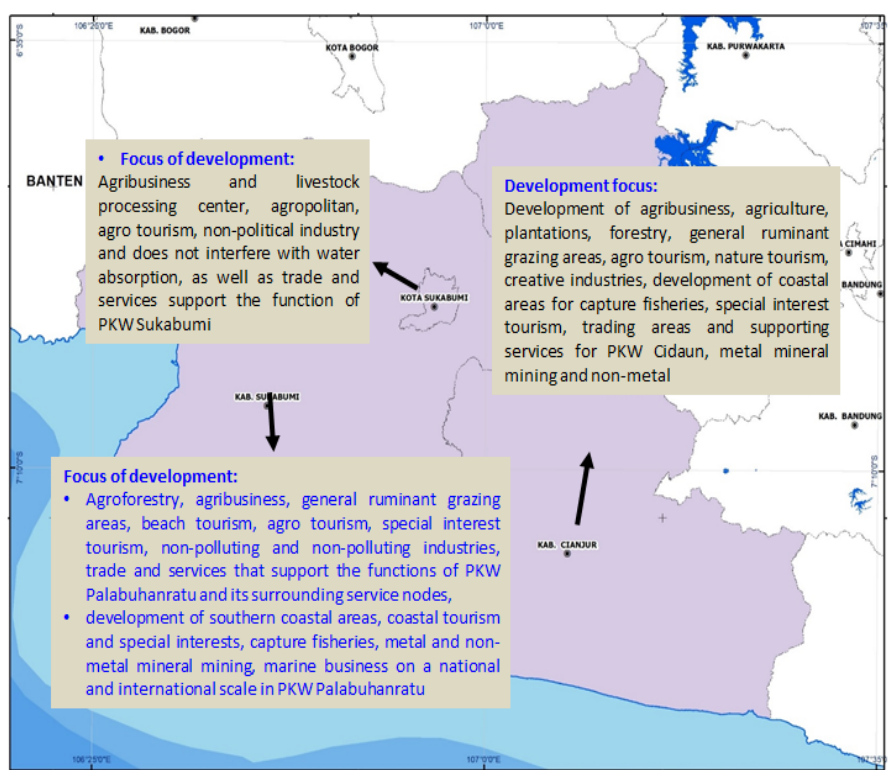

THE DEVELOPMENT DIRECTION :

1. Complete supporting facilities for PKW and PKL

2. Develop strategic infrastructure

3. Developing agribusiness, non-polluting industries and not disturbing water absorption, beach and agro tourism, and special interest tourism

4. Development of marine business that is environmentally sound by utilizing investment capital to generate global competitiveness

Figure 2: Directions for the Sukabumi Development Area (WP).

Source: Bappeda Provinsi Jawa Barat.

\section{Airports and their Strategic Functions in the Development of West Java Province}

Based on Law No.1 of 2009 concerning Aviation, every airport business operator is required to provide airport facilities that meet aviation safety and security requirements, as well as airport services following established service standards.

\section{Plans for the Establishment of a New Airport in Cikembar District, Sukabumi District, West Java Province}

An equitable development strategy, as stated in the Regional Medium-Term Development Plan (RPJMD) of the infrastructure development program. Cikembar Airport is targeted for completion in 2023. In the Decree of the Minister of Transportation of the Republic of Indonesia Number KM 75 of 2019, Cikembar airport, Sukabumi is designated as a hub airport with a tertiary service scale and is organized by the Airport Operators Unit of the Directorate General of Civil Aviation. The airport is located in Cimanggu Village and Cikembar Village, Cikembar District, Sukabumi District, West Java Province. With a land area provided of approximately 137.66 hectares. Collecting airports have a service area function as National Activity Centers (PKN) and Regional Activity Centers (PKW).

\section{Cikembar Airport Master Plan}

Attached to the Decree of the Minister of Transportation of the Republic of Indonesia Number KM 75 of 2019, the plan to develop Cikembar Airport is outlined in the Master Plan for the New Airport in Cikembar, Sukabumi District, West Java Province. The master plan includes basic data related to airport planning in general in the form of demand forecasts for passenger and cargo service needs, facility requirements, facility layout, development implementation stages, land use and needs, and safety areas for flight operations. The master plan becomes the basis for planning in the form of a Detailed Engineering Plan (RTT) for the main airport facilities. This master plan is stated to be valid for 20 (twenty) years and can be reviewed every 5 (five) years. The master plan is attached with planning data as shown in table 1. 
Table 1 Forecast Data on Demand for New Airport Transportation Services in Cikembar District, Sukabumi District, West Java Province

\begin{tabular}{|c|c|c|c|c|}
\hline \multirow[t]{2}{*}{ No } & \multirow[t]{2}{*}{ Description } & \multicolumn{2}{|c|}{ Stage } & \multirow[t]{2}{*}{ Information } \\
\hline & & Stage I & Stage II & \\
\hline \multirow[t]{4}{*}{$A$} & Passenger & & & \\
\hline & Anual & 110.60 & 665.280 & Passenger \\
\hline & Daily & 306 & 1.848 & Passenger \\
\hline & Busy time & 210 & 619 & Passenger \\
\hline \multirow[t]{3}{*}{ B } & Cargo & & & \\
\hline & International & - & - & \\
\hline & Domestic & 30 & 37 & Ton/day \\
\hline \multirow[t]{4}{*}{ C } & Pergerakan $\mathrm{F}$ & sawat & & \\
\hline & Anual & 1.440 & 6.120 & Movement \\
\hline & Daily & 3 & 17 & Movement \\
\hline & Busy time & 5 & 8 & Movement \\
\hline D & Anual & 2 & 4 & Plane \\
\hline$E$ & Daily & ATR-72 & $\begin{array}{l}\text { B-737 } \\
900 \mathrm{ER}\end{array}$ & \\
\hline $\mathrm{F}$ & Busy time & Bandung & Surabaya & \\
\hline
\end{tabular}

Source: Attachment to the Master Plan, Decree of the Minister of Transportation of the Republic of Indonesia Number KM 75 of 2019

\section{Literature Review}

\subsection{Airport Passenger Demand Model}

Potential demand for air transportation users is determined by various influencing factors, namely geographic factors, population size, motivation, and user habits ((Ashford: 2011). In predicting potential airport demand, the following factors need to be considered: first, availability. capacity, in this case, airports. Second, the general economic situation, both regionally, nationally, and globally Third, the socio-economic and demographic demographics of the population around the airport area Fourth, the factor of economic capacity in operating airport services Fifth, the level of competition between - airlines, sixth, the political environment and climate that affects the air transportation system and industry, seventh, technological achievements include aviation, telecommunications, navigation, and other related technologies transportation.

In the airport planning and design process, projecting the estimated number of passengers is an important stage because it will greatly affect the space program in determining airport facilities, especially in terminal buildings. Calculation errors at this stage will have an impact on uneconomical services and infrastructure, low work systems due to the mismatch of service loads with the facilities provided (Postorino, 2010). From a geographical point of view, the catchment area of an airport can be defined as an area that has the potential to serve potential users and passengers of the airport. While demand in the context of transportation is the number of services or facilities needed to serve the transportation of people and/or goods from a location or region (Akbardin and Permana, 2020)(Simbolon: 2003).

\section{Trend Analysis Method Model}

Forecasting with this method is a simple method commonly used in forecasting the number of passengers. The basis of this method is historical data from the variables studied, while the analysis is carried out by taking into account the trends in the development of existing data by assuming that these data determine variations that will continue to show similar relationships in the future. The forms of trend analysis models that are commonly used are the linear regression method (straight-line curve), the exponential equation method, and the exponential modification method.

\section{Research Methods}

In determining the potential demand for passengers at the Cikembar Airport terminal, primary and secondary data are collected in the form of documents from the authorities that are open in nature as well as statistical data relevant to forecasting potential demand. The data is then processed into time series data using the exponential smoothing forecasting method, namely the forecasting method by drawing a smooth curve from the average data development which is used 
as a reference in estimating the value in the coming years (Hillier: 2008). The analysis process in this study is as illustrated in the flow chart (Figure 3).

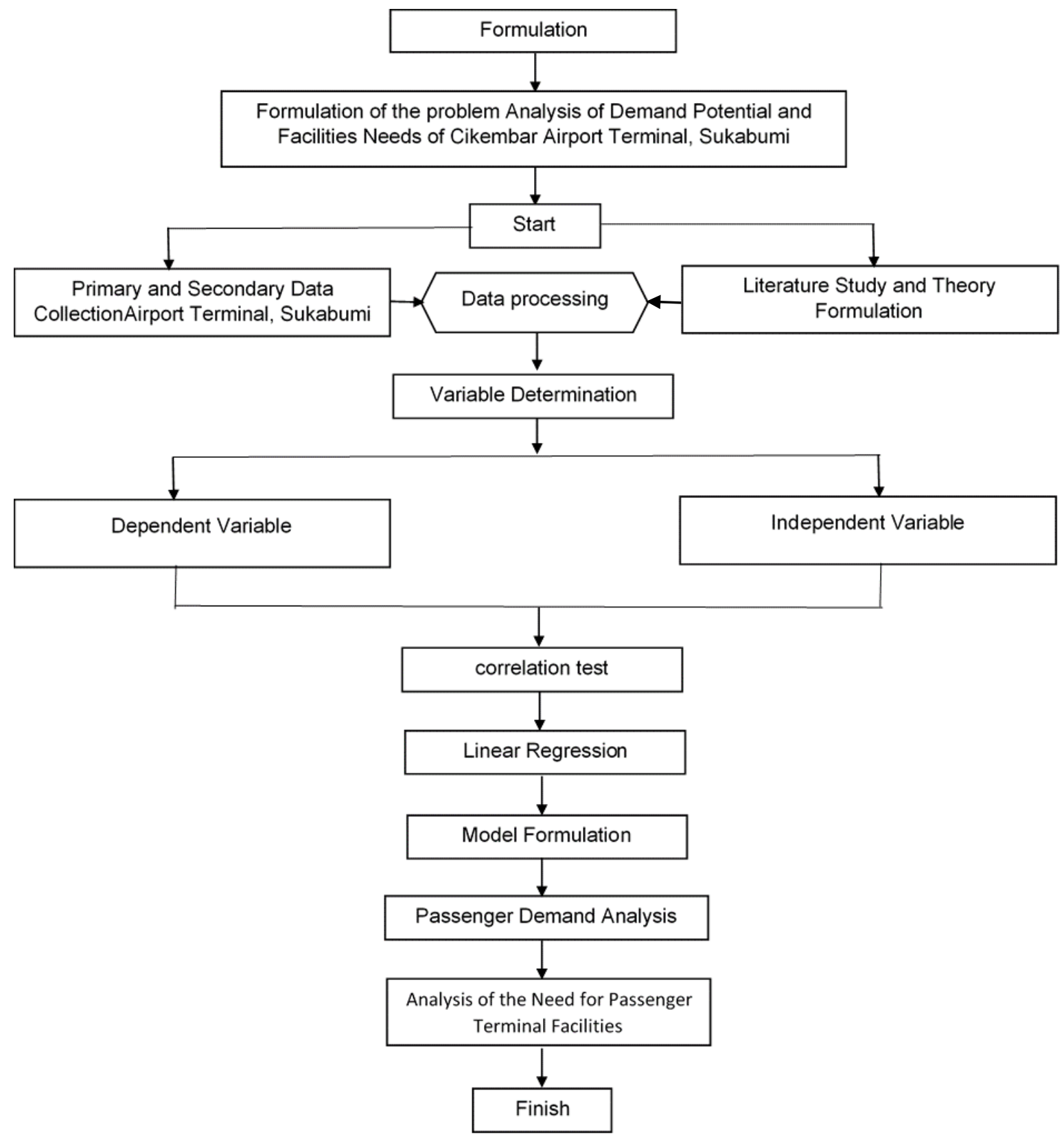

Figure 3: Research Flowchart

\subsection{Forecasting the Number of Passengers based on Potential Demand}

The required airport terminal facilities will depend on the results of the forecast to find the relationship between demand and the facility capacity requirements at the passenger terminal. To analyze and project the forecasting of the number of passengers based on demand, the method of correlation and multiple linear regression methods is carried out between the number of passengers as the dependent variable. Meanwhile, statistical variables such as population growth in the Sukabumi and West Java areas, the Gross Regional Domestic Product (PDRB) of the Sukabumi areas, and West Java were determined as independent variables. The regression equation model for passenger projection is (formula 1)

$$
Y=a 0+a 1 X 1+a 2 X 2+a 3 X 3+a 4 X 4+\ldots \ldots+a+a n
$$




\subsection{Determining the Need for Passenger Terminal Area}

The standard area for domestic passenger terminals is influenced by the number of annual busy time passengers as outlined in the Regulation of the Director-General of Civil Aviation Number SKEP.77 / VI / 2005, regarding the technical requirements for the operation of airport engineering facilities as shown in table 2 .

Table 2. Standard Area of Domestic Passenger Terminal

\begin{tabular}{cccl}
\hline \multirow{2}{*}{$\begin{array}{c}\text { Number of } \\
\text { Passengers / Year }\end{array}$} & \multicolumn{2}{c}{ Standard Terminal Area } & \\
\cline { 2 - 3 } & $\begin{array}{c}\text { m2 / Number of } \\
\text { Passengers at Busy Time }\end{array}$ & $\begin{array}{c}\text { Total } \\
(\mathbf{m} 2)\end{array}$ & \\
\hline $10.001-25.000$ & - & 120 & The standard area for this \\
$25.001-50.000$ & - & 240 & terminal includes a circulation \\
$50.001-100.000$ & - & 600 & area of 20\%, but it does not \\
$100.001-150.000$ & 10 & - & take into account commercial \\
$150.001-500.000$ & 12 & - & activities \\
$500.001-1.000 .000$ & 14 & - & X number of peak hour \\
$>1.000 .000$ & Calculated in more detail & - & passengers \\
\hline \multicolumn{2}{c}{ Source: Minister of Transportation Regulation Number KM 20 of 2005}
\end{tabular}

Meanwhile, in determining the detailed requirements for passenger terminal facilities, it is calculated based on the standards in the same regulations as detailed in table 3 .

Table 3. Standard Area of Domestic Passenger Terminal

\begin{tabular}{|c|c|c|c|}
\hline No. & Facilities & Formula & Unit \\
\hline 1 & $\begin{array}{l}\text { The length of the departure } \\
\text { curb }\end{array}$ & $L=0,095$ a.p $p(+10 \%)$ & $\mathrm{m}$ \\
\hline 2 & Departure Hall & $A=0,75\{a(1+f)+b\}$ & $\mathrm{m} 2$ \\
\hline 3 & Counter check-in & $N=((a+b) t 1) / 60(+10 \%)$ & unit \\
\hline 4 & Area check-in & $A=0,25(a+b)(+10 \%)$ & $\mathrm{m} 2$ \\
\hline 5 & Security Check (Centralized) & $N=(a+b) / 300$ & unit \\
\hline 6 & Gate hold room & $A=$ (m.s) & $\mathrm{m} 2$ \\
\hline 7 & Departure waiting room & $A=\{(u i+v k) / 30\}(+10 \%)$ & $\mathrm{m} 2$ \\
\hline 8 & Departure waiting room & $A=0,9 c m 2(+10 \%)$ & $\mathrm{m} 2$ \\
\hline 9 & $\begin{array}{l}\text { Baggage claim area } \\
\text { Luas Area }\end{array}$ & $\begin{aligned} N & =c . r / 300 \\
A & =N .350\end{aligned}$ & $\begin{array}{l}\text { unit } \\
\text { m2 }\end{array}$ \\
\hline 10 & Baggage claim Devices & $L=0,095$ c p (+10\%) & $\mathrm{m}$ \\
\hline 11 & The arrival curb & $\mathrm{L}=0,095 \mathrm{c} \mathrm{p}(+10 \%)$ & $\mathrm{m}$ \\
\hline 12 & The arrival Hall & $A=0,375(b+c+2 c f)(+10 \%)$ & $\mathrm{m} 2$ \\
\hline 13 & +Concenssion $17 \%$ & & $\mathrm{~m} 2$ \\
\hline 14 & $\begin{array}{l}\text { Parking Facilities } \\
\text { Parking area }\end{array}$ & $\begin{array}{c}N=\text { Jumlah PWS } \times 0,8 \\
A=N \times 35 \mathrm{~m} 2\end{array}$ & $\begin{array}{l}\text { unit } \\
\text { m2 }\end{array}$ \\
\hline
\end{tabular}

Source: Minister of Transportation Regulation Number KM 20 of 2005

\section{Results and Discussion}

\section{A. Analysis of Passenger Movement Projection}

\section{Data Collection and Interpretation}

Based on the Decree of the Minister of Transportation of the Republic of Indonesia Number KM 75 of 2019, Cikembar Airport is classified as a tertiary Collecting Airport (Hub). Referring to the definition of the Regulation of the Minister of Transportation of the Republic of Indonesia Number PM 39 of 2019 concerning the National Airport Order, airports with a tertiary service scale are one of the supporting infrastructures for the services of the nearest National Activity Center (PKN) and Regional Activity Center (PKW) which serves the highest number of passengers. low 500,000 (five hundred thousand) and less than 1,000,000 (one million) people per year.

Based on the 2018-2023 RPJMD of West Java Province, the development of Cikembar Airport is included in the priority of land transportation infrastructure development which is projected to be completed in 2023. Based on the Master Plan attached to KM 75 of 2019, Cikembar Airport in phase II is projected to have an annual passenger number of 665,280 inhabitants, with a daily number of passengers of 1,848 and peak hours of 619 . Regression 
analysis is needed to determine the number of annual passengers in 2023, which is when the physical construction of Cikembar Airport is completed and ready to operate.

The variables involved in the regression analysis are the statistical data records of Sukabumi District and West Java Province, each of which reflects the service areas of the Regional Activity Center and National Activity Center which include: 1) Number and population growth, 2) Number of foreign tourist visits and domestic tourists visiting and 3) Gross Regional Domestic Product (GRDP).

\section{Total Population}

The population projection that is used as a variable in the context of the Cikembar airport passenger projection is the population growth of Sukabumi District in 2016-2020 which reflects the services of the Regional Activity Center where Cikembar Airport is planned, along with West Java population growth which reflects the services of the National Activity Center (PKN).

Table 4. Population Growth of Sukabumi District in 2016-2020)

\begin{tabular}{ccc}
\hline Year & Population & $\begin{array}{c}\text { Growth } \\
\text { (\%) }\end{array}$ \\
\hline 2016 & 321.097 & \\
2017 & 323.788 & $0,8 \%$ \\
2018 & 326.282 & $0,8 \%$ \\
2019 & 328.680 & $0,7 \%$ \\
2020 & 330.691 & $0,6 \%$ \\
\hline \multicolumn{2}{c}{ Average } & $\mathbf{0 , 7 \%}$ \\
\hline
\end{tabular}

Source: BPS Sukabumi District

Table 5. West Java Population Growth 2016-2020

\begin{tabular}{ccc}
\hline Year & Population & $\begin{array}{c}\text { Growth } \\
(\%)\end{array}$ \\
\hline 2016 & 47.379 .389 & \\
2017 & 48.037 .827 & $1,4 \%$ \\
2018 & 48.683 .861 & $1,3 \%$ \\
2019 & 49.316 .712 & $1,3 \%$ \\
2020 & 49.935 .858 & $1,3 \%$ \\
\hline \multicolumn{2}{c}{ Average } & $\mathbf{1 , 3 \%}$ \\
\hline
\end{tabular}

Source: BPS West Java Province

\section{Number of Tourists}

The number and growth of foreign and domestic tourists are based on data from BPS Sukabumi District as presented in table 6.

Table 6. Number of International and Domestic Tourists in 2015-2018

\begin{tabular}{|c|c|c|c|c|c|c|}
\hline Year & International & Growth (\%) & Domestics & Growth (\%) & $\begin{array}{c}\text { Total } \\
\text { Travelers } \\
\text { (International } \\
\text { \& Domestics) }\end{array}$ & $\begin{array}{c}\text { Growth } \\
(\%)\end{array}$ \\
\hline 2015 & 115.548 & & 3.380 .193 & & 3.495 .741 & \\
\hline 2016 & 115.547 & $0 \%$ & 3.485 .066 & $3,1 \%$ & 3.600 .613 & $3,0 \%$ \\
\hline 2017 & 122.810 & $6,3 \%$ & 3.657 .767 & $5,0 \%$ & 3.780 .577 & $5,0 \%$ \\
\hline \multirow[t]{2}{*}{2018} & 127.145 & $3,5 \%$ & 3.719 .483 & $1,7 \%$ & 3.846 .628 & $1,7 \%$ \\
\hline & Average & $3,3 \%$ & Average & $3,2 \%$ & Average & $3,2 \%$ \\
\hline
\end{tabular}


Table 7. Number of International and Domestic Tourists in West Java Province 2012-2016

\begin{tabular}{ccccccc}
\hline Year & International & Growth (\%) & Domestics & Growth (\%) & $\begin{array}{c}\text { Total } \\
\text { Travelers } \\
\text { (International } \\
\text { \& Domestics) }\end{array}$ & $\begin{array}{c}\text { Growth } \\
\text { (\%) }\end{array}$ \\
\hline 2012 & 1.905 .378 & & & & 44.663 .441 & \\
2013 & 1.794 .401 & $-5,8 \%$ & 45.758 .063 & & 47.330 .580 & $6,0 \%$ \\
2014 & 1.962 .639 & $9,4 \%$ & 47.992 .088 & $5,4 \%$ & 49.954 .727 & $5,5 \%$ \\
2015 & 2.027 .629 & $3,3 \%$ & 56.334 .706 & $17,4 \%$ & 58.362 .335 & $16,8 \%$ \\
2016 & 4.428 .094 & $118,4 \%$ & 58.728 .666 & $4,2 \%$ & 63.156 .760 & $8,2 \%$ \\
\hline & Average & $\mathbf{3 1 , 3 \%}$ & Average & $\mathbf{8 , 4 \%}$ & Average & $\mathbf{3 , 2} \%$ \\
\hline
\end{tabular}

4. Produk Domestik Regional Bruto (PDRB)

Gross Domestic Product data describes the economic capacity of a region. In this study, the GRDP growth data of Sukabumi District and West Java Province were used as presented in table 8.

Table 8.Growth of GDP per Capita based on constant prices of Sukabumi District in 2016-2020

\begin{tabular}{ccc}
\hline Year & ID & $\begin{array}{c}\text { Growth } \\
(\%)\end{array}$ \\
\hline 2016 & 16.136 .280 & $5,4 \%$ \\
2017 & 17.002 .755 & $5,4 \%$ \\
2018 & 17.935 .085 & $5,5 \%$ \\
2019 & 18.922 .738 & $5,5 \%$ \\
2020 & 14.039 .069 & \\
\hline \multicolumn{2}{c}{ Average } & $\mathbf{5 , 4 \%}$ \\
\hline
\end{tabular}

Source: BPS Sukabumi District

Table 9.Growth of GDP per Capita based on West Java's constant prices in 2016-2020

\begin{tabular}{ccc}
\hline Year & ID & $\begin{array}{c}\text { Growth } \\
(\%)\end{array}$ \\
\hline 2016 & 26.923 .505 & $4,2 \%$ \\
2017 & 27.970 .918 & $3,9 \%$ \\
2018 & 29.161 .391 & $4,3 \%$ \\
2019 & 30.247 .470 & $3,7 \%$ \\
2020 & 25.310 .591 & \\
\hline \multicolumn{2}{c}{ Average } & $\mathbf{4 , 0 \%}$ \\
\hline \multicolumn{2}{c}{ Source: BPS West Java Province }
\end{tabular}

\section{Estimation of the Number of Passengers Based on the Trend of Increase}

From statistical data depicted on population growth factors, foreign and domestic tourist visits, and the economy represented by GRDP, an estimate of the number of passengers is made based on the projection year using the percentage growth of each variable.

Table 10. Estimated Number of Passengers $(Y)$ Based on the Percentage of the Independent Variable Increase Trend $(X)$

\begin{tabular}{|c|c|c|c|c|c|c|c|c|}
\hline & \multicolumn{2}{|c|}{ Total Population } & \multicolumn{4}{|c|}{ Number of tourists } & \multicolumn{2}{|c|}{ PDRB } \\
\hline & (X1) & (X2) & (X3) & (X4) & (X5) & (X6) & (X1) & (X1) \\
\hline $\begin{array}{c}\text { Tahun } \\
\text { Proyeksi }\end{array}$ & $\begin{array}{c}\text { The } \\
\text { populatio } \\
\text { n of } \\
\text { Sukabumi } \\
\text { District }\end{array}$ & $\begin{array}{c}\text { Total } \\
\text { population } \\
\text { of West } \\
\text { Java } \\
\text { Province }\end{array}$ & $\begin{array}{c}\text { Number of } \\
\text { tourists } \\
\text { int. } \\
\text { Sukabumi } \\
\text { district }\end{array}$ & $\begin{array}{c}\text { Number of } \\
\text { tourists } \\
\text { Domestic. } \\
\text { Sukabumi } \\
\text { district }\end{array}$ & $\begin{array}{c}\text { Number of } \\
\text { tourists } \\
\text { int. West } \\
\text { Java } \\
\text { Province }\end{array}$ & $\begin{array}{c}\text { Number of } \\
\text { tourists } \\
\text { Domestic } \\
\text { West Java } \\
\text { Province }\end{array}$ & $\begin{array}{c}\text { PDRB } \\
\text { Sukabu } \\
\text { mi } \\
\text { District }\end{array}$ & $\begin{array}{c}\text { PDRB } \\
\text { West } \\
\text { Java } \\
\text { Province }\end{array}$ \\
\hline 2019 & 665.280 & 665.280 & 665.280 & 665.280 & 665.280 & 665.280 & 665.280 & 665.280 \\
\hline 2020 & 670.195 & 674.078 & 687.045 & 686.891 & 873.597 & 721.036 & 701.479 & 691.961 \\
\hline 2021 & 675.146 & 682.993 & 709.522 & 709.204 & 1.147 .142 & 781.465 & 739.647 & 719.711 \\
\hline 2022 & 680.134 & 692.025 & 732.735 & 732.242 & 1.506 .343 & 846.959 & 779.892 & 748.575 \\
\hline 2023 & 685.159 & 701.177 & 756.707 & 756.029 & 1.978 .018 & 917.941 & 822.327 & 778.596 \\
\hline
\end{tabular}


In predicting potential demand, three comparison scenarios are determined, namely the optimistic scenario for the highest value, the moderate scenario for the medium value, and the pessimistic scenario for the lowest value as depicted in table 11.

Tabel 11. Comparison based on 3-time scenarios in 5 years

\begin{tabular}{lccccc}
\hline & $\mathbf{2 0 1 9}$ & $\mathbf{2 0 2 0}$ & $\mathbf{2 0 2 1}$ & $\mathbf{2 0 2 2}$ & $\mathbf{2 0 2 3}$ \\
\hline $\begin{array}{l}\text { Optimistic } \\
\text { Scenarios }\end{array}$ & 665.280 & 873.597 & 1.147 .142 & 1.506 .343 & 1.978 .018 \\
$\begin{array}{l}\text { Moderate } \\
\text { Scenarios }\end{array}$ & 665.280 & 686.891 & 709.204 & 732.242 & 756.029 \\
$\begin{array}{l}\text { The Pessimistic } \\
\text { Scenario }\end{array}$ & 665.280 & 670.195 & 675.146 & 680.134 & 685.159 \\
\hline
\end{tabular}

Among the scenario choices mentioned above, a moderate scenario was chosen with the following considerations: 1) The Sukabumi area and its surroundings have a large enough potential for visits with an abundance of available tourist objects but it requires a tourism development program from the local government so that it takes time to develop. 2) The Sukabumi area and its surroundings are quite far from the nearest accessible airports, namely Soekarno-Hatta Airport in Cengkareng, Banten, and Husein Sastranegara Airport in Bandung so that the establishment of a new airport in this area has the potential to be the main choice chosen from the distance factor but requires infrastructure support transportation which takes time to develop.

\section{Correlation Analysis}

Correlation analysis is carried out to see the closest relationship between the estimated number of passengers as the dependent variable and the independent variables, namely population, number of tourists, and GRDP. Correlation analysis was performed using SPSS software.

Table 12. Correlation Analysis Using SPSS Software

\begin{tabular}{|c|c|c|c|c|c|c|c|c|c|}
\hline & $\begin{array}{c}\text { Passeng } \\
\text { er }\end{array}$ & $\underset{\mathrm{mi}}{\text { Pddk_Sukabu }}$ & $\begin{array}{c}\text { Pddk_We } \\
\text { st Java }\end{array}$ & $\begin{array}{c}\text { Int. } \\
\text { Tourists_Sukab } \\
\text { umi }\end{array}$ & $\begin{array}{c}\text { Domestic } \\
\text { Tourists_Sukab } \\
\text { umi }\end{array}$ & $\begin{array}{c}\text { Int. } \\
\text { Tourists_W } \\
\text { est Javat }\end{array}$ & $\begin{array}{c}\text { Domestic } \\
\text { Tourists } \\
\text { West } \\
\text { Java }\end{array}$ & $\underset{\mathrm{mi}}{\text { Pdrb_Sukabu }}$ & $\begin{array}{c}\text { Pdrb_We } \\
\text { st Java }\end{array}$ \\
\hline \multirow[t]{2}{*}{ Passenger } & 1 & $.998^{* *}$ & $1.000^{* *}$ & $.951^{*}$ & $.984^{*}$ & 0,754 & $.976^{* \star}$ & $-0,209$ & $-0,094$ \\
\hline & & 0,000 & 0,000 & 0,049 & 0,016 & 0,141 & 0,004 & 0,736 & 0,880 \\
\hline \multirow[t]{2}{*}{ Pddk_Sukabumi } & $.998^{* *}$ & 1 & $.999^{* *}$ & 0,941 & $.987^{*}$ & 0,709 & $.970^{* *}$ & $-0,146$ & $-0,030$ \\
\hline & 0,000 & & 0,000 & 0,059 & 0,013 & 0,180 & 0,006 & 0,815 & 0,962 \\
\hline \multirow{2}{*}{$\begin{array}{c}\text { Pddk_West } \\
\text { Java }\end{array}$} & $1.000^{* *}$ & $.999^{* *}$ & 1 & 0,946 & $.986^{*}$ & 0,735 & $.973^{* *}$ & $-0,183$ & $-0,068$ \\
\hline & 0,000 & 0,000 & & 0,054 & 0,014 & 0,157 & 0,005 & 0,768 & 0,914 \\
\hline \multirow{2}{*}{$\begin{array}{c}\text { Int. } \\
\text { Tourists_Sukab } \\
\text { umi }\end{array}$} & $.951^{*}$ & 0,941 & 0,946 & 1 & $.951^{*}$ & 0,889 & 0,931 & $.955^{*}$ & $.955^{*}$ \\
\hline & 0,049 & 0,059 & 0,054 & & 0,049 & 0,111 & 0,069 & 0,045 & 0,045 \\
\hline \multirow{2}{*}{$\begin{array}{c}\text { Int. } \\
\text { Tourists_Sukab } \\
\text { umi }\end{array}$} & $.984^{*}$ & $.987^{*}$ & $.986^{*}$ & $.951^{*}$ & 1 & 0,721 & 0,896 & $.983^{*}$ & $.988^{*}$ \\
\hline & 0,016 & 0,013 & 0,014 & 0,049 & & 0,279 & 0,104 & 0,017 & 0,012 \\
\hline \multirow{2}{*}{$\begin{array}{c}\text { Int. } \\
\text { Tourists_West } \\
\text { Javat }\end{array}$} & 0,754 & 0,709 & 0,735 & 0,889 & 0,721 & 1 & 0,721 & $-0,797$ & $-0,723$ \\
\hline & 0,141 & 0,180 & 0,157 & 0,111 & 0,279 & & 0,169 & 0,106 & 0,168 \\
\hline \multirow{2}{*}{$\begin{array}{c}\text { Domestic } \\
\text { Tourists West } \\
\text { Java }\end{array}$} & $.976^{* *}$ & $.970^{* *}$ & $.973^{* *}$ & 0,931 & 0,896 & 0,721 & 1 & $-0,175$ & $-0,066$ \\
\hline & 0,004 & 0,006 & 0,005 & 0,069 & 0,104 & 0,169 & & 0,779 & 0,915 \\
\hline \multirow[t]{2}{*}{ Pdrb_Sukabumi } & $-0,209$ & $-0,146$ & $-0,183$ & $.955^{*}$ & $.983^{*}$ & $-0,797$ & $-0,175$ & 1 & $.993^{* *}$ \\
\hline & 0,736 & 0,815 & 0,768 & 0,045 & 0,017 & 0,106 & 0,779 & & 0,001 \\
\hline \multirow[t]{2}{*}{ Pdrb_West Java } & $-0,094$ & $-0,030$ & $-0,068$ & $.955^{*}$ & $.988^{*}$ & $-0,723$ & $-0,066$ & $.993^{* *}$ & 1 \\
\hline & 0,880 & 0,962 & 0,914 & 0,045 & 0,012 & 0,168 & 0,915 & 0,001 & \\
\hline
\end{tabular}




\section{Linear Regression Analysis}

Linear regression analysis was carried out to obtain the basic factor for forecasting the number of passengers based on the percentage of the annual upward trend under the moderate scenario.

Table 13. Number of Passenger Regression Analysis Table $(\mathrm{Y})$ with an annual increase trend $(\mathrm{X})$

\begin{tabular}{cccccc}
\hline Year & $\begin{array}{c}\text { Year to- } \\
\mathbf{n}(\mathbf{X})\end{array}$ & $\begin{array}{c}\text { Total } \\
\text { passenger }(\mathbf{Y})\end{array}$ & $\mathbf{X 2}$ & $\mathbf{Y 2}$ & $\mathbf{X Y}$ \\
\hline 2019 & 1 & 665.280 & 1 & 442.597 .478 .400 & 665.280 \\
2020 & 2 & 686.891 & 4 & 471.819 .464 .323 & 1.373 .782 \\
2021 & 3 & 709.204 & 9 & 502.970 .798 .023 & 2.127 .613 \\
2022 & 4 & 732.242 & 16 & 536.178 .862 .454 & 2.928 .969 \\
2023 & 5 & 756.029 & 25 & 571.579 .450 .878 & 3.780 .144 \\
\hline $\boldsymbol{\Sigma}$ & $\mathbf{1 5}$ & $\mathbf{3 . 5 4 9 . 6 4 7}$ & $\mathbf{5 5}$ & $\mathbf{2 . 5 2 5 . 1 4 6 . 0 5 4 . 0 7 8}$ & $\mathbf{1 0 8 7 5 7 8 8 , 4 4}$ \\
\hline $\mathrm{n}$ & 5 & & & & \\
\hline
\end{tabular}

Source: Analysis

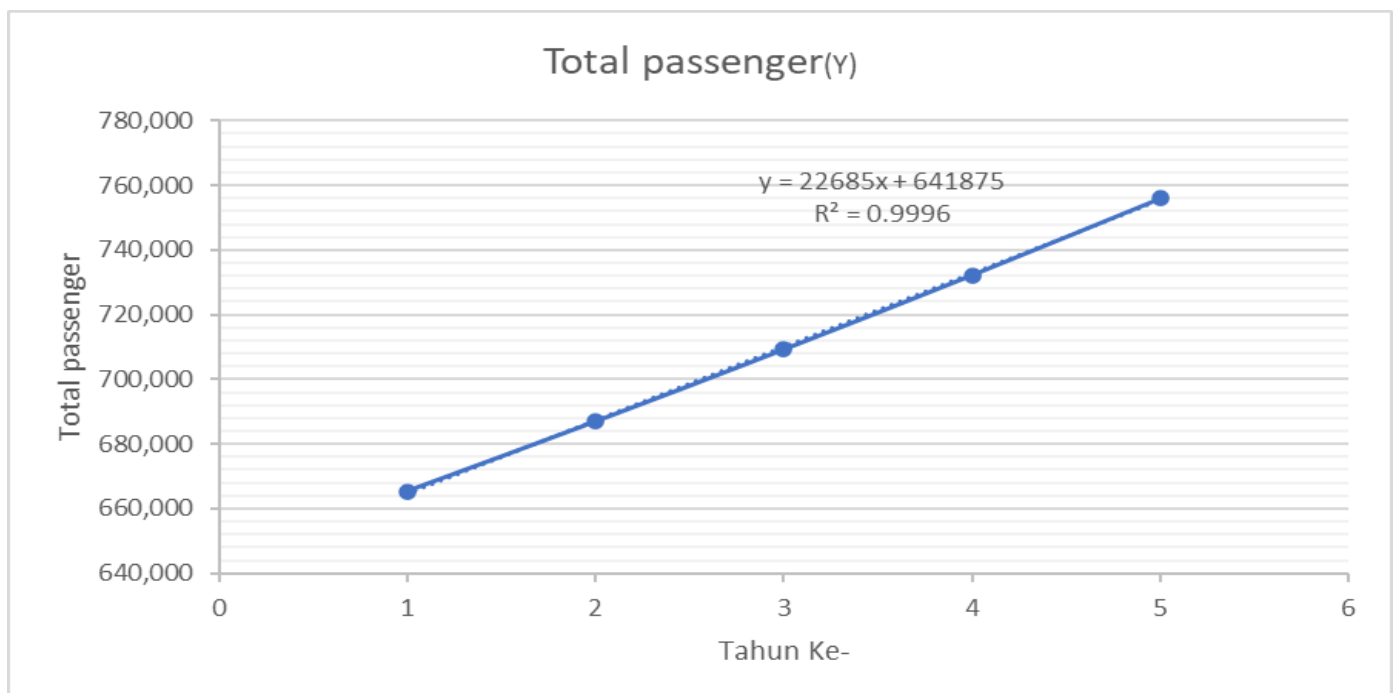

Figure 3: Linear Regression Curve for the Number of Passengers at Cikembar Airport Terminal. Source: Analysis

Based on the results of the calculation of regression analysis using Microsoft Excel software, the results obtained $y$ (number of passengers) $=22685 x+641875$, with $R^{2}=0.9996$.

\section{Passenger Forecasting and Standard Terminal Area}

Based on the forecasting database, the forecast of the number of passengers based on demand can be projected along with the area requirements of the passenger terminal with the calculations in table 14.

Table 14. Forecasting Number of Passengers and Standard Terminal Area

\begin{tabular}{cccccc}
\hline Year & $\begin{array}{c}\text { Year } \\
\text { to-n }(\mathbf{X})\end{array}$ & $\begin{array}{c}\text { Total } \\
\text { passenger } \\
(\mathbf{Y})\end{array}$ & $\begin{array}{c}\text { Standard } \\
\text { Operational } \\
\text { Terminal } \\
\text { Area }\end{array}$ & $\begin{array}{c}\text { Concession } \\
\text { Area } \\
\text { (Assuming } \\
\mathbf{3 0 \% )}\end{array}$ & $\begin{array}{c}\text { Total } \\
\text { Terminal } \\
\text { Area }\end{array}$ \\
\hline 2019 & 1 & 665.280 & 7.451 & 3.074 & 10.245 \\
2020 & 2 & 686.891 & 7.693 & 3.173 & 10.578 \\
2021 & 3 & 709.204 & 7.943 & 3.277 & 10.922
\end{tabular}




\begin{tabular}{cccccc}
\hline Year & $\begin{array}{c}\text { Year } \\
\text { to-n }(\mathbf{X})\end{array}$ & $\begin{array}{c}\text { Total } \\
\text { passenger } \\
(\mathbf{Y})\end{array}$ & $\begin{array}{c}\text { Standard } \\
\text { Operational } \\
\text { Terminal } \\
\text { Area }\end{array}$ & $\begin{array}{c}\text { Concession } \\
\text { Area } \\
\text { (Assuming } \\
\mathbf{3 0 \% )}\end{array}$ & $\begin{array}{c}\text { Total } \\
\text { Terminal } \\
\text { Area }\end{array}$ \\
\hline 2022 & 4 & 732.242 & 8.201 & 3.383 & 11.277 \\
2023 & 5 & 756.029 & 8.468 & 3.493 & 11.643 \\
2024 & 6 & 777.985 & 8.713 & 3.594 & 11.981 \\
2025 & 7 & 800.670 & 8.968 & 3.699 & 12.330 \\
2026 & 8 & 823.355 & 9.222 & 3.804 & 12.680 \\
2027 & 9 & 846.040 & 9.476 & 3.909 & 13.029 \\
2028 & 10 & 868.725 & 9.730 & 4.014 & 13.378 \\
2029 & 11 & 891.410 & 9.984 & 4.118 & 13.728 \\
2030 & 12 & 914.095 & 10.238 & 4.223 & 14.077 \\
2031 & 13 & 936.780 & 10.492 & 4.328 & 14.426 \\
2032 & 14 & 959.465 & 10.746 & 4.433 & 14.776 \\
2033 & 15 & 982.150 & 11.000 & 4.538 & 15.125 \\
2034 & 16 & 1.004 .835 & 11.053 & 4.559 & 15.198 \\
2035 & 17 & 1.027 .520 & 11.303 & 4.662 & 15.541 \\
2036 & 18 & 1.050 .205 & 11.552 & 4.765 & 15.884 \\
2037 & 19 & 1.072 .890 & 11.802 & 4.868 & 16.227 \\
2038 & 20 & 1.095 .575 & 12.051 & 4.971 & 16.571 \\
2039 & 21 & 1.118 .260 & 12.301 & 5.074 & 16.914 \\
2040 & 22 & 1.140 .945 & 12.550 & 5.177 & 17.257 \\
2041 & 23 & 1.163 .630 & 12.800 & 5.280 & 17.600 \\
2042 & 24 & 1.186 .315 & 13.049 & 5.383 & 17.943 \\
2043 & 25 & 1.209 .000 & 13.299 & 5.486 & 18.286 \\
2044 & 26 & 1.231 .685 & 13.549 & 5.589 & 18.629 \\
2045 & 27 & 1.254 .370 & 13.798 & 5.692 & 18.972 \\
2046 & 28 & 1.277 .055 & 14.048 & 5.795 & 19.315 \\
2047 & 29 & 1.299 .740 & 14.297 & 5.898 & 19.659 \\
2048 & 30 & 1.322 .425 & 14.547 & 6.001 & 20.002 \\
\hline & & & & & 5045. \\
\hline
\end{tabular}

Source: Analysis

By using a moderate increase trend approach, the estimated number of passengers at Cikembar Airport's passenger terminal in 2023, namely the year the airport is planned to be realized, is 756,029 passengers with 605 passengers at a busy time (PWS). The operational area needed for the terminal in that year was $8,468 \mathrm{~m} 2$. Assuming the concession area is $30 \%$, the total terminal area is $11,643 \mathrm{~m} 2$. This area projection is still following the estimated terminal area attached to the master plan, which is $12,000 \mathrm{~m} 2$. The forecasting table shows the projection of passenger area needs to be based on the projection year. It can be seen that in 2025, with an estimated passenger number of 800,670 passengers, the required terminal area has already exceeded the estimated terminal area according to the master plan, so further calculations will be required for airport expansion planning.

\section{B. Analysis of Airport Facility Requirements}

The formulation of the need for airport facilities can be determined by referring to the provisions stipulated in the Regulation of the Minister of Transportation KM No. 20 of 2005, concerning the technical requirements for the operation of airport engineering facilities as follows:

\section{B1. Departure Terminal}

1. Length of the Kerb of Departure

The length of the departure curbs uses the following formula:

$$
L=0,095 \text { a.p (+10\%) }
$$


where,

$\mathrm{L}=$ Length of the Kerb of Departure $(\mathrm{m})$

$a=$ Number of passengers departing at busy times

$\mathrm{p}=$ Proportion of Passengers Using Car / Taxi

So that the length of the departure curb is:

$$
\mathrm{L}=(0,095 \times 302 \times 1,5) \times 1,1=47 \mathrm{~m}
$$

\section{Departure Hall}

To calculate the area of the departure hall, you can use the following formula:

where,

$$
A=0,75\{a(1+f)+b\}+10 \%
$$

A = Depature Hall (m2)

$a=$ Number of passengers departing at busy times

$\mathrm{b}=$ Number of transfer passengers

$f=$ Number of deliverers / passengers (2 people)

So that the required departure hall area is:

$$
A=(0,75(302(1+2)+2) \times 1,1=771 \mathrm{~m} 2
$$

\section{The Check-In Area}

The check-in area must be able to accommodate passengers at busy times during queuing and making transactions at this check counter. The approximate area of this is:

where,

$$
A=0,25(a+b)+10 \%
$$

$A=$ The check-in area $(\mathrm{m} 2)$

$\mathrm{a}=$ Number of passengers departing at busy times

$\mathrm{b}=$ Number of transfer passengers

So that the required check-in area is:

$$
A=(0,25 \times(302+121)) \times 1,1=116 \mathrm{~m} 2
$$

\section{Number of Check-in Counters}

The number of check-in counters uses a formula:

$$
N=((a+b) t 1) / 60(+10 \%)
$$

So that the required number of check counters is:

$$
N=(((302+121) 2) / 60)) \times 1,1=16 \text { unit }
$$

\section{Departure Waiting Room}

The departure waiting room must be sufficient to accommodate busy-time passengers while waiting for check-in time, and as long as passengers wait while boarding after check-in. The formula for calculating the area of the departure waiting room is as follows:

where,

$$
A=C-((u . i+v . k) / 30)+10 \%
$$

$A=$ Departure waiting room $(\mathrm{m} 2)$

$\mathrm{C}=$ Number of passengers departing at busy times

$\mathrm{u}=$ Longest average waiting time (60 minutes)

$i=$ Proportion of passengers waiting for the longest

$\mathrm{v}=$ Fastest average waiting time (20 minutes)

$\mathrm{k}=$ Proportion of passengers waiting fastest $(0.4)$ 
So that the required departure waiting room:

$$
A=(302-((60 \times 0,6)+(30 \times 0,4))) \times 1,1=399 \mathrm{~m} 2
$$

\section{Seats}

The approximate number of seats can be calculated using a formula:

where,

$$
N=1 / 3 \times a
$$

$\mathrm{N}=$ number of seats required

$\mathrm{a}=$ number of busy time passengers

So that the number of seats that need to be:

$$
N=1 / 3 \times 302=101 \text { unit }
$$

\section{B2. Arrival Terminal}

\section{Length of Arrival Curb}

The length of the arrival curb can be calculated by the formula:

where,

$$
L=0,095 \text { a.p (+10\%) }
$$

$L=$ Length of arrival curb $(m)$

$\mathrm{a}=$ Number of passengers departing at busy times

$\mathrm{p}=$ Proportion of Passengers Using Car / Taxi

So the length of the departure curb is:

$$
L=(0,095 \times 302 \times 1,5) \times 1,1=47 \mathrm{~m}
$$

\section{Baggage claim area}

The approximate area of this area can be calculated using the following formula:

where,

$$
A=0,9 c+10 \%
$$

$A=$ the area of the baggage claim area $(\mathrm{m} 2)$

$\mathrm{C}=$ Number of passengers departing at busy times

So that the required baggage claim area is

$$
A=(0,9 \times 302) \times 1,1=299 \mathrm{~m} 2
$$

\section{Arrival Hall}

The arrival hall must be large enough to accommodate incoming passengers and pick-up passengers at busy times. The approximate area is calculated using a formula:

where,

$$
A=0,375(b+c+2 . c . f)+10 \%
$$

A $=$ Arrival hall area $(m 2)$

$b=$ Number of transfer passengers

$\mathrm{c}=$ Number of passengers departing at busy times

$f=$ Number of deliverers $/$ passengers $(2$ people)

So that the required arrival hall area is:

$$
A=(0,375(121+302+(2 \times 302 \times 2)) \times 1,1=675 \mathrm{~m} 2
$$




\section{B3. Supporting Facilities}

1. Parking Needs

The amount of parking space required can use the formula for the number of busy time passengers multiplied by 0.8 :

\section{Required parking space $=0,8 \times 605=484$ Lot \\ With a large parking area $=484 \times 35=16.935 \mathrm{~m} 2$}

\section{Trolley needs}

The number of trolleys needed can use a formula:

$$
N=(w \times a) / 10
$$

where,

$\mathrm{N}=$ Number of trolleys (unit)

$\mathrm{w}=$ Number of hand gags per Passenger (assuming 2 handbags per passenger)

$a=$ Number of Passengers Busy Departure Time

so the number of trolleys needed is:

$$
N=(2 \times 302) / 10=60 \text { unit }
$$

Following are the results of the calculation of the facilities needed for Cikembar Sukabumi airport:

\begin{tabular}{|l|l|r|}
\hline No & \multicolumn{1}{|c|}{ Facilities } & \multicolumn{1}{|c|}{$\begin{array}{r}\text { Requirements } \\
\text { Calculation }\end{array}$} \\
\hline A & Departure Terminal & $47 \mathrm{~m}$ \\
\hline 1 & Length of the Kerb of Departure & $771 \mathrm{~m} 2$ \\
\hline 2 & Departure Hall & $116 \mathrm{~m} 2$ \\
\hline 3 & The Check-In Area & $16 \mathrm{unit}$ \\
\hline 4 & Number of Check-in Counters & $399 \mathrm{~m} 2$ \\
\hline 5 & Departure Waiting Room & $101 \mathrm{unit}$ \\
\hline 6 & Seats & $47 \mathrm{~m}$ \\
\hline B & Arrival Terminal & $288 \mathrm{~m} 2$ \\
\hline 1 & Length of Arrival Curb & $675 \mathrm{~m} 2$ \\
\hline 2 & Baggage claim area & \\
\hline 3 & Arrival Hall & $16.935 \mathrm{~m} 2$ \\
\hline C & Supporting Facilities & $60 \mathrm{unit}$ \\
\hline 1 & Parking Needs & \\
\hline 2 & Trolley needs &
\end{tabular}

\section{Coclusion}

Based on the calculation of potential demand for passenger numbers, it can be estimated that the demand for passengers at Cikembar Airport is up to 30 years from the issuance of the master plan in 2019, namely in 2048, counting $1,322,425$ passengers with the required terminal area of 20,002 m2. As for the context of the airport development plan in 2023 according to the West Java Provincial Medium Term Development Plan (RPJMD) 2018-2023, the number of passengers is estimated to be 756,029 passengers with a terminal operational area that must be provided covering an area of $8,468 \mathrm{~m} 2$ or still covering an area of $12,000 \mathrm{~m} 2$ with assuming a concession area of $30 \%$.

\section{Acknowledgments}

In writing this article, we would like to thank those who have helped both in providing data and in the data analysis process. 


\section{References}

Akbardin, J., \& Permana, A. Y. (2020). The Characteristics Study Of Parking User Behavior Toward Location Accessibility Of Non-Commercial Activities Center. International Journal of Advanced Science and Technology, 29(7), 3293-3300.

Ashford, N. J., Mumayiz, S., \& Wright, P. H. (2011). Airport engineering: planning, design, and development of 21 st century airports. John Wiley \& Sons. Chatterjee, S., \& Hadi, A. S. (2015). Regression analysis by example. John Wiley \& Sons.

BAPPEDA Provinsi Jawa Barat. 2019. Pra Musrenbang Kewilayahah Provinsi Jawa Barat tahun 2019 untuk Penyusunan RKPD Provinsi Jawa barat tahun 2020. http://bappeda.jabarprov.go.id/documents/pra-musrenbang-provinsi-jawa-barat-tahun-2019

Hiller, F., \& Hiller, M. (2003). Introduction to management science: a modeling and case studies approach with spreadsheets (ed.). New York, NY: McGraw-Hill.

Keputusan Menteri Perhubungan KM No 47 tahun 2002 tentang Sertifikasi Operasi Bandar Udara

Keputusan Menteri Perhubungan Republik Indonesia Nomor KM 75 Tahun 2019 Tentang Penetapan Lokasi Bandar Udara Baru Di Cikembar Kabupaten Sukabumi Provinsi Jawa Barat

Peraturan Menteri Perhubungan KM Nomor 25 tahun 2005 Tentang Penyelanggaraan Angkutan Udara

Peraturan Menteri Perhubungan Republik Indonesia Nomor PM 39 Tahun 2019 Tentang Tatanan Kebandarudaraan Nasional

Perda No 22 Tahun 2010 Tentang RTRWP Jawa-Barat 2009-2029

Permana, A. Y., \& Wijaya, K. (2017). Spatial change transformation of educational areas in Bandung Spatial change transformation of educational areas in Bandung. IOP Conference Series: Earth and Environmental Science, 99, 012029. https://doi.org/10.1088/17551315/99/1/012029

Postorino, M. (2010). Air Demand Modelling: Overview and Application to a Developing regional Airport. Development of Regional Airports-Theoretical Analyses and Case Studies.

Rencana Pembangunan Jangka Menengah Daerah (RPJMD) Provinsi Jawa Barat tahun 20182023

Simbolon, M Maringan. 2003. Ekonomi Transportasi. Ghalia Indonesia: Jakarta.

Statistik, B. P. (2019). Produk Domestik Regional Bruto Kabupaten Sukabumi Menurut Lapangan Usaha, 2014-2018.

Statistik, B. P. (2021). Kabupaten Sukabumi dalam Angka 2021

Sefrus, T., Priyanto, S., \& Irawan, M. Z. (2017). Analisis Awal Permasalahan Transportasi Udara dan Arah Pengembangan Bandara di Indonesia. Jurnal Transportasi, 17(3).

SKEP no.77/VI Tahun 2005

SNI 03-7046-2004 tentang Terminal Penumpang Bandar Udara

Undang-undang No. 1 Tahun 2009 tentang Penerbangan 